\title{
Correlation of Supervision Process and the Performance of the Graduate Program in Faculty of Education Mahachulalongkornrajavidyalaya University
}

\author{
Boonchurd Chumnisart ${ }^{1}$, Phra Surachai Surachayo², Uthai Satiman ${ }^{3}$, Phramaha Prayoon \\ Teravaro(Trakran) ${ }^{4}$ \\ 1,2,3,4 Faculty of Education, Mahachulalongkornrajavidyalaya University \\ booncherd.chu@mcu.ac.th, ${ }^{2}$ surachai.sur@mcu.ac.th, ${ }^{3}$ surachaihongtrakool@gmail.com, ${ }^{4}$ bananajon_01@hotmail.com
}

\begin{abstract}
The objectives of this research were 1) to study the supervision process and the performance of the graduate program, 2) to study the correlation of the supervisory components and the performance of the graduate program, 3) to assess the supervision process related to the performance of the graduate program in Faculty of Education Mahachulalongkornrajavidyalaya University with empirical data. Mixed methods research was designed. Research sample consisted of 500 samples, and research tools were interview form and questionnaires. Data were analyzed by using descriptive statistics, Pearson correlation analysis, and analyzed factors of the supervision and the performance by computer software packages. Research results indicated that 1) appropriate supervision process and the performance of graduate programs were classified into five main processes, 64 sub-processes. 2) All supervisory and performance components were significantly correlated at the .001 level, with a correlation coefficient range from .054 to .620 , which able to be analyzed for the process. 3) The validation of the supervision process related to the performance of the graduate program in Faculty of Education Mahachulalongkornrajavidyalaya University found that it was fit with empirical data, and analysis results were $\mathrm{x}^{2}=103.82, \mathrm{df}=84, \mathrm{p}=0.07$, Goodness of Fit Index (GFI) was .98, Adjusted Goodness of Fit Index (AGFI) was 0.94, Root Mean Square Residual (RMR) was .14 and Root Mean Square Error of Approximation (RMSEA) was .02, indicating that the model was consistent with the empirical data. Therefore, the supervision process correlated to the performance of the graduate program
\end{abstract}

Keywords

Supervision Process, Performance, Graduate Program, Department of Educational Administration

Article Received: 10 August 2020, Revised: 25 October 2020, Accepted: 18 November 2020

\section{Introduction}

Nowadays, Thai society is rapidly changing in various fields, resulting in many crises in society, including economic, social, political, cultural, and environmental crises, which also resulted in a demand for educational reform. Education is a real tool for economic, social, cultural and political development of the country. The goals of the education must be aiming to create society in a manner that contributes to the development of the nation as a whole aiming to produce people or learners that are directly productive with attributes, potential and the ability to develop oneself and society towards success. Student learning centered is an important way to create and develop students to achieve the attributes needed in the globalization era because it is a teaching and learning that focuses on the learners. Learners are encouraged to learn by themselves, learning in a subject that corresponds to their own abilities and needs. They have developed their full potential. This educational management concept is rooted in educational philosophy and various learning theories that have been developed continuously for a long time. It is a proven approach that can effectively develop learners to have the desired characteristics and aiming for all learners to have the ability to learn and develop themselves. It is considered that the learner is the most important in accordance with the Learning Management Guidelines of the National Education Act 1999 that teachers must have the capacity to manage learning to have high quality standards in accordance with national curriculum and educational standards. The school has the capacity to develop into the system quality assurance and upgrading of the school's leading of the Office of the Basic Education Commission that is ready to become an international standard school (World-Class Standard School). All personnel must be involved in the provide education to become a school with a learner development system, educational institutions, learning resources, curriculum and learning environments that enable learners to demonstrate self-development, progressing according to their needs up to the international level [1].

Supervision task is one of the most important events in the organization and management of educational institutions. Supervision is an educational process that aims to promote, support, and to develop standards of education, especially supervisors need knowledge, experience and skills in supervision must be encouraged, morale and encouragement. Cooperation from all parties involved in education is one of the important tasks for school administrators, and co-administrators is supervision, especially in the school supervision. It is one way to help improve the quality of education which will help to improve the technical shortcomings for development and promote teaching and learning to achieve objectives. School administrators and co-administrators are being close to teachers and students, and students will be more aware of problems than outside personnel. School supervision will accurately and appropriately meet the needs of school personnel [2].

Supervision is the process of developing quality education personnel, and be able to keep up with the situation, 
educational policies, courses and various elements. The importance of supervision consists of; 1) to develop academic, knowledge, educational innovation, education management policy curriculum that there are rapid and continuous adjustments. 2) To keep up with the changing political, economic and social conditions with constant adjustments. 3) To solve problems in education management in order to prevent errors in education management and to cause creativity in education management. 4) To raise educational standards. The person who will perform supervisory duties must have the following qualifications: 1) Knowledge, must have knowledge understanding of teaching theory and learning management as well as other relevant elements resulting directly to the learning of the learner. In addition, you must know about the behavior of the person. 2) Skills must have good teaching skills, have communication skills, and problem-solving optimism. 3) Attitude must be a person with good character, attention, work-minded, responsibility, diligence, courteous, friendly, selfless and devoted to work [3].

The operation of the Department of Educational Administration, the Department of Educational Administration, opened on July 1, 1961, under the name of the Academic Department of 2526 B.E. Department of Educational Administration, 1992, Faculty of Education expanded the classroom from Wat Mahathat, and come to Phrapariyattham School, Ministry of Education, Wat Srisudaram Bangkhunnon Subdistrict Bangkoknoi District Bangkok on June 1, 1992 with the help of Phra Vachirarajamanit. Later, 3 school buildings with 4 floors each, were built and opened in 2013 as a place to study for students of the Faculty of Education, Department of Educational Administration provides education, one area of study, namely the Educational Administration Branch, 1998. The work section was improved according to the Mahachulalongkornrajavidyalaya University Act, 1997. Department of Administration changed its name to The Department of Educational Administration and Sangha Affairs provides two academic disciplines: Educational Administration and Non-school Education. In 2005, it was revised the bachelor degree curriculum in accordance with the announcement of the Office of the Higher Education Commission (OHEC) as a five-year course, providing education in two disciplines as before and opened a master's degree in one discipline, namely Educational Administration. In 2009, the Faculty of Education moved its office to Mahachulalongkornrajavidyalaya University, at 79 Moo 1, Phahon Yothin Road (Km.55), Lam Sai Sub-district, Wangnoi District, Phra Nakhon Si Ayutthaya Province 13170. In 2011, a Master of Arts program has supported for opening in Academic Service Branches, 4 locations: Khon Kaen Campus Nakhon Sawan Buddhist College and Nakhon Si Thammarat campus. The year 2019 has opened a Master of Arts program in the Buddhist Educational Administration branch, Loei Sangha College, is the fifth place in the administration of education [4] which the curriculum encourages students who have studied within the curriculum to have professional skills by allowing students 1) to develop their educational profession, educational administration and various forms of educational management correctly in accordance with modern academic principles and in line with the needs of society, 2) able to demonstrate academic leadership and be a leader of knowledge and ideas and apply knowledge to society appropriately, 3) be able to supervise or advise education, to create knowledge and understanding for teachers, students, parents or stakeholders to recognize the importance of education as a tool for the development of people in society, 4) able to manage an educational institution which is an organization with administrative factors such as personnel, budget, buildings materials, equipment, and continuous development, 5) able to develop courses to organize student activities, to provide academic work, teaching and promoting students' skills in a consistent and effective manner, 6) to measure and assess learning outcomes, educational quality assurance has been achieved for the objectives, and academic procedures can be integrated into education to be more efficient, 7) being a person in the moral, ethical and professional ethics which can be a role model for teachers, students and the community.

For the graduation criteria for that program, one of the criteria is to pass professional educational administration training. According to the criteria set by the course the curriculum includes an educational professional development course with the objective of enabling students to study the spirit and ideology of executives, Buddhist professional development, professional management, professional institution or organization professional standards for educational institution administrators, teacher production process and professional management, managing administrative knowledge, professional development research, and an educational administration professional training course, which is a course that is mandatory for all students. Students need to pass 90 hours of educational administration professional practice in order for students to study and practice in educational professional development, academic leadership, supervision or guidance school administration, teaching and learning courses, measuring and evaluating learning outcomes affairs and student activities, morality and ethics and professional ethics, educational quality assurance under the guidance of management as mentors and teacher supervision integrating Buddhism with the administration of educational institutions [5].

The researcher is therefore interested in study the supervision process related to the performance of the graduate program, Department of Educational Administration, Faculty of Education, Mahachulalongkornrajavidyalaya University to guide the study as well as practice guidelines for teachers of the principles of graduate studies Department of Educational Administration, Faculty of Education, Mahachulalongkornrajavidyalaya University, and those interested in the supervisory process and the performance of the graduate program to be a model of integration into the supervision manual and practice in developing graduate programs to be effective in working in response to university policies.

\section{Research Objectives}

The objectives of this research were 1) to study the supervision process and the performance of the graduate program, 2) to study the correlation of the supervisory components and the performance of the graduate program, 
3) to assess the supervision process related to the performance of the graduate program in Faculty of Education Mahachulalongkornrajavidyalaya University with empirical data.

\section{Research Methods}

\section{A. Research design}

The research on the supervision process and the performance of the graduate program, Department of Educational Administration, Faculty of Education, Mahachulalongkornrajavidyalaya University was conducted by mixed methods research including quantitative research and qualitative research.

\section{B. Research Process}

Step 1: to study the supervision process and performance of the graduate program, Department of Educational Administration, Faculty of Education, Mahachulalongkornrajavidyalaya University has 2 steps: step 1 was to study documents on the supervision process and performance of the graduate program. Department of Educational Administration, Faculty of Education Based on books, textbooks, websites and related research. The document study was analyzed by content analysis. Step 2 was interviewing executives, faculty members, graduate program staff, Department of Educational Administration, Faculty of Education, Mahachulalongkornrajavidyalaya University, all 5 places, 10 key informants in the supervision process and performance of the graduate program, Department of Educational Administration. Research tool was interview form and data was analyzed by content analysis resulting in the supervisory process and performance of the graduate program, Department of Educational Administration, Faculty of Education.

Step 2: to study the supervisory components and the performance of the graduate program, Department of Educational Administration, Faculty of Education, Mahachulalongkornrajavidyalaya University has 2 steps: Step 1, the results of the study document. The results of interviews, supervision and performance components of the graduate program, Department of Educational Administration, Faculty of Education. Data was analyzed by content analysis. The result is the supervisory and operational components of the graduate program, Department of Educational Administration, Faculty of Education (Draft 1). Step 2 Seminar for expert group to develop supervisory process and performance of graduate program, Department of Educational Administration, Faculty of Education, Mahachulalongkornrajavidyalaya University, with 6 experts in the supervision process and performance of the graduate program, Department of Educational Administration, Faculty of Education. The tools used are guide to focus group discussion, supervision process, and practice of Graduate Programs Department of Educational Administration, Faculty of Education. Content analysis was used. The end result is the supervisory and operational processes of the graduate program, Department of Educational Administration, Faculty of Education, Mahachulalongkornrajavidyalaya University.
Step 3: To assess the supervision process in relation to the performance of the graduate program, Department of Educational Administration, Faculty of Education, Mahachulalongkornrajavidyalaya University with empirical data has 3 steps: Step 1, distribute questionnaires, supervisory processes related to the performance of the graduate program, Department of Educational Administration, Faculty of Education, with 500 samples of administrators, faculty, staff and students of the Master of Education Program and a doctorate course, Department of Educational Administration using questionnaires. Data analysis were analyzed by mean, standard deviation, skewness, kurtosis, and distribution coefficient. Supervision processes related to the performance of the graduate program, Department of Educational Administration using Confirmatory Factor Analysis (CFA). Stage 2, examines the consistency of the supervision process in relation to the performance of the graduate program, Department of Educational Administration with empirical data from the supervision process related to the performance of the graduate program, Department of Educational Administration with empirical data created with a computer program with a computer verify the consistency of assessing the supervision process in relation to the performance of the graduate program. Department of Educational Administration with evidence-based Exploratory Factor Analysis (EFA). The results are the consistency of assessing the governance process in relation to the performance of the graduate program, Department of Educational Administration and empirical data. Step 3 evaluate the supervisory process in relation to the performance of the graduate program, Department of Educational Administration by administrators, faculty, staff and students of the Master of Education Program and a doctorate course, Department of Buddhist Educational Administration. Questionnaire tool was assessed possibility, accuracy, suitability, usefulness. The analysis of data, mean and standard deviation of the crisis-solving process, the transition to a new lifestyle base management with empirical data, resulted in a supervisory process related to the performance of the graduate program, Department of Educational Administration, Faculty of Education, Mahachulalongkornrajavidyalaya University.

\section{Results}

1. The results of research on the supervision process and performance of the graduate program, Department of Educational Administration, Faculty of Education, Mahachulalongkornrajavidyalaya University, found that the study of documents resulted in the supervision process and performance of the graduate program, Department of Educational Administration, Faculty of Education, Mahachulalongkornrajavidyalaya University was divided into 5 main processes: 1) Supervisory process consisting of 15 processes, 2) Supervisory component has 9 processes, 3) Performance component consists of 16 processes, 4 ) The main objective of Iddhipada IV consists of 12 processes, 5) Supervision related to the performance of the curriculum has an important objective consisting of 12 processes and 64 processes. 
2. The results of analysis of supervisory components and performance of the graduate program, Department of Educational Administration, Faculty of Education, Mahachulalongkornrajavidyalaya University

The results of the descriptive statistical analysis of variables used in the affirmative component analysis, the linkage of educational administration for sustainable development. The statistical values used were mean, standard deviation (SD), skewness (Sk), Kurtosis (Ku), and distribution coefficient (CV). For administrative factors, the highest mean was 4.07, followed by the Buddhist management component with an average of 4.07 , the administrative characteristics of 4.01 , the administrative goals had an average of 3.97 and the component with the lowest mean the educational administration for sustainable development was 3.94 and the distribution of the data was similar to the normal curve. When looking at the sampling factor, it was found that most of the components had negative values, indicating that the distribution characteristics of the data were less than the normal curve. The information is not distributed much. When considering the distribution coefficient (C.V.), it was found that the data were similar. There is a small distribution of information as shown in Table 1 as follows.

Table 1 Descriptive statistics of the characterization of the supervisory and operational components of Graduate Program,Department of Educational Administration, Faculty of Education, Mahachulalongkornrajavidyalaya University

\begin{tabular}{|c|c|c|c|c|c|}
\hline $\begin{array}{c}\text { Supervisory and } \\
\text { operational components } \\
\text { of Graduate Program. } \\
\text { Department of } \\
\text { Educational } \\
\text { Administration }\end{array}$ & Mean & S.D. & Sk & $\mathrm{Ku}$ & C.V \\
\hline 1. Supervision process & 4.23 & 0.442 & -0.496 & -0.333 & 0.05 \\
\hline $\begin{array}{l}\text { 2. Components of } \\
\text { supervision }\end{array}$ & 4.24 & 0.436 & -0.567 & 0.398 & 0.08 \\
\hline $\begin{array}{l}\text { 3. Components of } \\
\text { performance }\end{array}$ & 4.15 & 0.329 & -0.263 & -0.298 & 0.07 \\
\hline 4. Principle & 4.17 & 0.371 & 0.049 & -0.715 & 0.12 \\
\hline $\begin{array}{l}\text { 5. Supervision related to } \\
\text { the performance of the } \\
\text { curriculum. }\end{array}$ & 3.96 & 0.421 & -0.375 & -0.373 & 0.03 \\
\hline
\end{tabular}

Exploratory Factor Analysis (EFA) results of analysis of the relationship between supervisory components and the performance of the graduate program. The Department of Educational Administration found that all the components had a significant relationship at the 0.001 level with the correlation coefficient range from 0.054 to 0.762 . Supervision process (Sum A) and performance component (Sum C) was 0.762 , followed by supervisory component (Sum B) and operating efficiency component (Sum C) was equal to 0.678 , the lowest correlated pair, the supervisory process (Sum A) and the supervisory process related to the course performance (Sum E) was 0.054 when considering the Bartlett's Test of Sphericity was 889.019 p-value (sig) = 0.00 indicates the correlation matrix. There were statistically significant differences between the two affirmative elements from the identity matrix. When considering the KaiserMeyer-Olkin measure of Sampling Adequacy, it was found to be 0.741 , indicating that the components were related. It is appropriate to analyze the supervision process related to the performance of the graduate program. Department of Educational Administration, Faculty of Education, Mahachulalongkornrajavidyalaya University was very good and able to be used for process analysis. Summarizing the results of the relationship analysis of the supervisory components and the performance of the graduate program Department of Educational Administration was at the .001 level, the correlation coefficients ranged from 0.054 to 0.762 . The correlation matrix characteristics between the components were significantly different from the identity matrix. Statistical and the components were related enough able to analyze the process.

1. The results of evaluation of the supervision process related to the performance of the graduate program, Department of Educational Administration, Faculty of Education, Mahachulalongkornrajavidyalaya University with empirical data according to the measurement model used to evaluate the supervision process related to the performance of the graduate program. Department of Educational Administration, Faculty of Education, Mahachulalongkornrajavidyalaya University and the empirical data (Full Model) consisted of 5 main processes, 64 processes. Analysis results found that the model was consistent with the empirical data by considering the ChiSquare $=103.82$, $\mathrm{df}=84, \mathrm{p}=0.07$, which differs significantly from zero, Goodness of Fit Index (GFI) is 0.98 , Adjusted Goodness of Fit Index (AGFI) is 0.94, Root Mean Square Residual (RMR) is 0.14 and Root Mean Square Error of Approximation (RMSEA) is 0.02, indicating that the model is consistent with the empirical data as shown in Fig. 1.

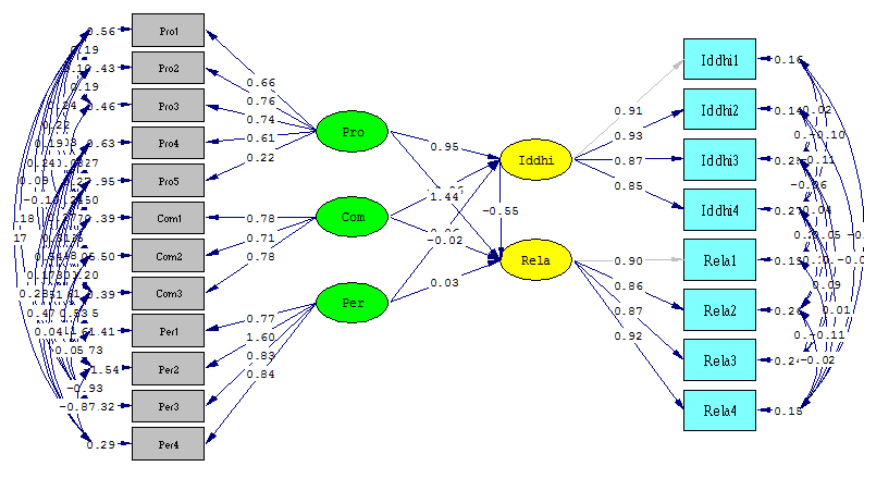

Fig. 1 Supervision Process and the Performance of the Graduate Program

The results of the audit and assess the supervision process related to the performance of the graduate program, Department of Educational Administration, Faculty of Education, Mahachulalongkornrajavidyalaya University with empirical data by distributing questionnaires, it was found that the supervision process was related to the performance of the graduate program, Department of Educational Administration, Faculty of Education, Mahachulalongkornrajavidyalaya University with empirical data overall, it is at a high level. When considering from a descending side, it was found that accuracy (4.05), feasibility and suitability (4.07), usefulness (4.03). 


\section{Discussion}

The researcher found important points to discuss the results of the supervision process related to the performance of the graduate program, Department of Educational Administration, Faculty of Education, Mahachulalongkornrajavidyalaya University as follows:

1. Results of research on the supervision process and performance of the graduate program. The Department of Educational Administration, Faculty of Education, Mahachulalongkornrajavidyalaya University, found that the study of documents resulted in the supervision process and performance of the graduate program, Department of Educational Administration, Faculty of Education, Mahachulalongkornrajavidyalaya University was divided into 5 main processes: 1) supervisory process consisting of 15 processes, 2) supervisory component has 9 processes, 3 ) performance component consists of 16 processes, 4 ) The main objective of Iddhipada IV consists of 12 processes, 5) supervision related to the curriculum performance has an important objective consisting of 12 processes, totaling 64 processes that related to the research of Jintanasak PhuAram which conducted the research on "The presentation of the autonomous school management model for Thailand" [6] concluded the study that the presented format consists of 4 parts: part 1, the introduction, the context and the background of the concept. Part 2 is the autonomous school administration model for Thailand consists of 5 components: 1) the principles and concepts in the formulation. This includes the principles of decentralization, emphasizing the main participation, rights and benefits of individuals, groups of people, organizations in obtaining and providing basic education. Principles of independence from the rules that apply to general schools. Principles have laws to support the state of the school, principles of verifiable readiness and quality-oriented education management principles, 2) Objectives of the model to provide an alternative to education management that allows individuals, groups, organizations to jointly establish or participate, 3) The characteristics of autonomous schools consist of meaning, charter, founder, sponsor, authorization of establishment, school type, number of schools admission, the freedom of management, government subsidies and verifiable responsibilities, 4) Charter of autonomous schools, 5) Public school administration. It is administered by the school board of directors and school administration under the supervision of the state in 4 areas, namely academic work, personnel work, finance and general administration work. Part 3 was guideline for model utilization that focus on accelerating the implementation of laws to support the operation of the autonomous school. There is a pilot project. Part 4 The conditions or limitations of the important model are the need to support law and the selection of school administrators and school administrators with the ability to meet the needs. "Motivating Factors Affecting Operational Efficiency: A Case Study of the Special Operations Battalion 1 (Commando) of the Air Force" [7]. Operations of special operations personnel Special Operations Battalion 1 (Commando) Air Force found to be at a high level. As for the motivating factor that contributes to the efficiency of performance of special operations staff, including job advancement opportunities and benefits relationship to the operational efficiency of special operations personnel. Other factors include planning participation, enhancement of knowledge, ability, age, education level, income (salary rate and gratuity), grade level, and length of service no relationship with Staff performance and in accordance with Pornsri Uchi studied internal supervision problems of Rayong Panyanukul School, Rayong Province, Office of Special Education Administration [8] in general, the difference was moderate when considering the aspects with a high level difference was the aspect of morale and morale, and the moderate difference was the evaluation of supervision. There are 3 aspects that are different, namely the understanding and preparation of supervision, supervision planning and the supervisory operations.

2. The results of the analysis of the relationship between supervision components and the performance of the graduate program, Department of Educational Administration found that all the elements had a significant relationship at the 0.001 level with the correlation coefficient range from 0.054 to 0.762 . Supervision process (Sum A) and performance component (Sum C) was 0.762, followed by supervisory component (Sum B) and operating efficiency component (Sum C) was equal to 0.678, the lowest correlated pair, the supervisory process (Sum A) and the supervisory process related to the course performance (Sum E) was 0.054 when considering the Bartlett's Test of Sphericity was 889.019 p-value (sig) $=0.00$ indicates the correlation matrix. There were statistically significant differences between the two affirmative elements from the identity matrix. When considering the Kaiser-Meyer-Olkin Measure of Sampling Adequacy, it was found to be 0.741, indicating that the elements were related. It is appropriate to analyze the supervision process related to the performance of the graduate program, Department of Educational Administration, Faculty of Education, Mahachulalongkornrajavidyalaya University was very good, able to be used for process analysis summarizing the results of the relationship analysis of the supervisory components and the performance of the graduate program, Department of Educational Administration at the 0.001 level, the correlation coefficients ranged from 0.054 to 0.762 . The correlation matrix characteristics between the components were significantly different from the identity matrix Statistics. The components are correlated enough which be able to analyze the process. This research is consistent with the research of Kanawalabhorn Klinnimnuan researched on "Office management efficiency Phitsanulok Province According to the principle of succession of Iddhipada IV "[9]. The results of comparing the opinions of personnel on Management efficiency of Phitsanulok Provincial Office according to the principle of influence of Iddhipada IV classified by factors personally, the respondents found that personnel with different gender, age, education level, position and income had a view on the management efficiency of Phitsanulok Provincial Office according to the principle of virtue of Iddhipada IV. When considering on a case-by-side basis, it was found that personnel of different sexes had views on the management efficiency of the Phitsanulok Provincial Office according to the Iddhipada IV principles of Wimangsa, which were statistically significant at the .05 level. In order to improve the efficiency of the administration of Phitsanulok Provincial Office, personnel 
should always have a desire, passionate, love to perform their work, desire to perform their work for greater results, be diligent in their work with hard and patient effort. Do not give up, must be aware of the mission that is assigned by the work with the mind, the mind does not let the mind be distracted, devote yourself to a work that is truly practiced, and always use wisdom to contemplate, inspect, rationalize, examine even more loose points of such work. It is important to know the planning, measure results and devise solutions, improve work to be better all the time and also found that it is consistent with the research of Apichai Chatupornvatee has conducted research on "Factors Affecting the Performance of Probation Volunteers Nakhon Sawan Province "[10]. The research results showed that 1) factors affecting the performance of the provincial probation volunteers, Nakhon Sawan, overall, was at a high level $(\mu=$ 3.79). When considered on a particular aspect, it was found that surveillance, assistance, supervision and report writing were at high levels in all aspects. 2) Relationship between personal factors and efficiency in the work of probation volunteers in Nakhon Sawan Province: gender, age, marital status, education, occupation, income, working period, probation volunteers. It was found that the personal factors of the control volunteers. The behavior did not correlate with the performance of the probation volunteers, thus rejecting the research hypothesis. Relationship between operational factors and the performance of Probation volunteers, it was found that operational factors were related to the efficiency of the performance of the probation volunteers in all aspects was statistically significant at the level of 0.1 , except for factors that on the practice of training and seminars, the assignment aspect is related to the effectiveness of the report writing probation volunteers' performance was significant statistical at level 0.05 .

3. Results of evaluation of the supervision process related to the performance of the graduate program. Department of Educational Administration, Faculty of Education, Mahachulalongkornrajavidyalaya University with empirical data according to the measurement model used to evaluate the supervision process related to the performance of the graduate program, Department of Educational Administration, Faculty of Education, Mahachulalongkornrajavidyalaya University and the empirical data (Full Model) consisted of 5 main processes, 64 processes, found that the model was consistent with the empirical data by considering the Chi-Square $=103.82$, df $=$ 84, $\mathrm{p}=0.07$, which differs significantly from zero, Goodness of Fit Index (GFI) is 0.98, Adjusted Goodness of Fit Index (AGFI) is 0.94, Root Mean Square Residual (RMR) is 0.14 and Root Mean Square Error of Approximation (RMSEA) is 0.02, indicating that the model is consistent with the empirical data, related with the research of Theerayut Liengsomboon that conducted research on "Factors affecting operational efficiency. According to the views of the government officials and Nan Provincial Administrative Organization employees, "[11] the study found that the factors affecting the efficiency of work according to the views of the government officials and Nan Provincial Administrative Organization employees were at a high level. When considering each aspect, it was found that the aspects affecting the efficiency of perform duties according to government officials and employees at the highest level, the first is the lifestyle, followed by the administration in terms of job satisfaction. The environment in the work and the incentive to work compare the factors affecting the efficiency of working according to the opinions of government officials and employees of the Nan Provincial Administrative Organization in all 5 areas, it was found that in general there was no statistically significant difference at the level of 0.05. Opinions and recommendations about guidelines for adding factors affecting work efficiency according to government officials' views and employees of Nan Provincial Administrative Organization, including administrative suggest that the main morality and ethics in management in terms of job satisfaction suggest that personnel should have participate in planning. The operating environment suggested that the equipment should be supported modern communication and the lifestyle. It is also suggested that Sufficiency economy should be applied in life and operational incentives. It is suggested that training courses should be provided to develop operational potential.

\section{Recommendations}

\section{A. Recommendations for Practices}

1. Relevant organizations should promote the policy of budget and organize development projects for administrators, faculty, staff and students in accordance with the curriculum objectives.

2. Organizations involved in supervisory processes related to performance able to apply supervisory processes related to operations to develop other areas in response to the policy, vision and mission of Mahachulalongkornrajavidyalaya University

\section{B. Recommendations for Future Research}

For this research, the researcher collected data from administrators, lecturers, staff and students of the Master of Education Program and a doctorate course in the field of Buddhist Educational Administration only, the next research should collect data from the administrators, faculty, staff and students of Mahachulalongkornrajavidyalaya University and study the components of loyalty related to the performance of personnel in order to develop the operational potential of Mahachulalongkornrajavidyalaya University personnel in response to the university's vision, mission and strategy to develop the university to be a world-class Buddhist university in the midst of a changing society.

\section{Conclusion}

Supervision process related to the performance of the graduate program, Department of Educational Administration, Faculty of Education, Mahachulalongkornrajavidyalaya University, had a consultation meeting before the supervision of supervision jointly plan the supervision according to the clear supervisory practice procedures to provide knowledge and understanding of what will be carried out in the supervision by the performance of the supervisor such as the lecturer of the supervisory management course, which has a proportion 
that clear and fair, praise and appropriate merit, provide opportunities to express opinions to supervisors and students. The evaluation of the past performance is brought to improve and give additional knowledge about supervision in order to enhance supervision with the performance of the principles of Iddhipada IV in Buddhism, namely, satisfaction in supervision. It is a practice work by function persistence consider various tasks with conscientiousness, combining innovative technology for effective supervision and operation.

\section{References}

[1] Ministry of Education, National Education Act. 1999 and the amendment (2nd edition), 2002, Bangkok: Teachers Council of Lat Phrao Publishing House, 1999.

[2] K. Prididilok, Administration and supervision of an introductory study, 1st edition, Bangkok: Aksara Pipat Company Limited, 2009.

[3] P. Tipayasuk, New educational supervision, https://www.gotoknow.org/posts/213347

[Online date 18 July 2020]

[4] Department of Educational Administration Faculty of Education, http://www.edmcu.net/site2558/?page_id = 5176 [Online August 18, 2020]

[5] Department of Educational Administration, Faculty of Education, Mahachulalongkornrajavidyalaya

University, Master of Buddhism Department of Buddhist Education (Curriculum revised in 2017), pages 40-24.

[6] J. Sakphu-aram, "Presentation of the Autonomous School Administration Model for Thailand", Doctor of Education Thesis, (Educational Administration), Graduate School: Chulalongkorn University, 2002.

[7] K. Methip, "Motivating Factors Affecting Operational Efficiency: Study in the Case of Special Operations Battalion 1 (Commando) Air Force", Master's Thesis, Graduate School Mahachulalongkornrajavidyalaya University, 2003.

[8] P. Uchi, Internal Supervision Problems of Rayong Panyanukul School, Rayong
Province Office of Special Education Administration, Thesis of Master Degree, Educational Administration, Faculty of Education, Burapha University, 2555.

[9] K. Klinnimnuan, "Efficiency of Management of Phitsanulok Provincial Office according to the principle of Iddhipada IV", Thesis of Master Degree, Graduate School

Mahachulalongkornrajavidyalaya University), 2011.

[10] A, Jatuponvatee, "Factors Affecting the Performance of Probation Volunteers Nakhon Sawan Province ", Thesis of Master Degree (Public Administration), Graduate School: MahachulalongkornrajavidyalayaUniversit y, 2014.

[11] T. Liengsomboon, "Factors Affecting Operational Efficiency According to the views of government officials and employees of Nan Provincial Administrative Organization ", Master of Public Administration, Graduate School Uttaradit Rajabhat University, 2009. 